\title{
Children and health effects of war Being a war child...
}

\section{Çocuklar ve savaşın sağlık etkilleri Bir savaş çocuğu olmak...}

Nurcan Çelik ${ }^{1}$ Saliha Özpınar ${ }^{1}$

${ }^{1}$ Faculty of Health Sciences, Manisa Celal Bayar University, Manisa, Turkey

Corresponding author: Saliha Özpmar, Faculty of Health Sciences, Manisa Celal Bayar University, Manisa, Turkey

E-mail:salihaozpinar@gmail.com

Received/Accepted: September 22, 2017 / September 22, 2017

Conflict of interest: There is not a conflict of interest.

\section{SUMMARY}

It's predicted that almost 10 million children as died at wars during the last decade, almost 300 thousand children fight more than 30 engagement area. Situations arising from armed conflict effect first of all children in various ways for they are defenseless and vulnerable.

Children health are affected in different ways by experiencing death, injuries, disablement, torture, rape, diseases psychological effects, forcing to migration, child soldiers, lack of education, loss of parents, socio-cultural changes because of war. Thousands of children die or become permanently disabled because of injuries of firearms or mines during war. However it's accepted as war crime in Convention on the Rights of the Children, children are employed as soldiers, exposed to sexual harassment. War and violence force millions of people to leave their homes. During migration, 5\% of children lose their parents. Mortality is very high among children separated from their families because of war. $85 \%$ of the deaths are seen within the first 2 days after reaching to refugee camps. Other children are experiencing problems, such as loss of language and tradition, and disapproval in the regions. For these reasons, thousands of children are forced to carry the negative effects of the war throughout their lives.

Destructive effect of war would manifest in different ways, degrees because of the factors as age, gender. Girls experience more emotional way the effects of war; while boys internalized the situation, reflects their feelings with more behavioral disorder. Gender, age, developmental period features should be considered in rehabilitation woks and coping mechanism for short-long terms should be composed in that direction. Children, who exposed physical, sexual harassment, lose one's family members should have priority for rehabilitation.

A society which has unhealthy children couldn't be healthy society in the future. Therefore implementation of rehabilitation programs for war-torn children should be bringing into force as soon as possible. It's important to act in the frame of Convenient of Rights of Children by considering the future well-being of the society. It's tried to assess health effects of war to children, approaches to war-torn children in this article.

Keywords: Children, War, Health.

ÖZET

Son 10 yıl boyunca, yaklaşık 10 milyon çocuğun savaşlarda öldüğü ve yaklaşık 300 bin çocuğun 30'dan fazla çatışma bölgesinde savaşmakta olduğu tahmin edilmektedir. Silahlı çatışmalar sonucu ortaya çıkan durumlar savunmasız ve incinebilir olmaları nedeniyle öncelikle çocukların sağlıklarını etkilemekte ve bunu pek çok değişik şekilde yapmaktadir.

Savaş nedeniyle çocuk sağlığı ölüm, yaralanma ve sakatlanma, hastalık, işkence ve tecavüz, psikolojik etkilenme, göçe zorlanma, eğitimden yoksun kalma, ebeveyn kaybı, sosyo-kültürel değişim yaşayarak çeşitli şekillerde etkilenebilmektedir. Çocuk Haklarına Dair Sözleşmesinde savaş suçu olarak kabul edilmesine rağmen çocuklar asker olarak kullanılmakta ve cinsel şiddet sistematik olarak uygulanmaktadır. Evlerini terk etmeye zorlanan çocukların \% $\%$ 'i göç sırasında ailelerini kaybetmektedir. Savaş sonucu ailesinden ayrılmış çocuklar arasında mortalite çok yüksektir. Ölümlerin \%85'i mülteci kamplarına ulaştıktan sonraki ilk 2 gün içinde görülmektedir. Diğer çocuklar ise, dil ve gelenek kaybı, göçtükleri bölgelerde kabul görmeme gibi sorunlar yaşamaktadırlar. Bu nedenlerden dolayı, çocukların binlercesi savaşın olumsuz etkilerini yaşamları boyunca üzerlerinde taşımak zorunda kalmaktadır. 
Ayrıca Yaş, cinsiyet gibi faktörler çocuklarda savaşın yıkıcı etkilerinin farklı şekil ve derecede ortaya çıkmasına neden olmaktadır. Savaşın etkilerini kız çocukları daha duygusal yaşarken; erkekler durumu içselleştirip, dışa vurarak daha fazla davranışsal bozukluğu gösterirler. Rehabilitasyon çalışmalarında çocukların cinsiyeti, yaşı, gelişimsel dönem özellikleri dikkate alınmalı, kısa ve uzun vadeli başa çıkma mekanizmaları bu doğrultuda oluşturulmalıdır. Fiziksel ve cinsel şiddete uğramış, aile üyelerini kaybetmiş çocuklara öncelikli sıra verilmelidir.

Çocukları sağlıklı olmayan bir toplumun gelecekte sağlıklı bir toplum olması düşünülemez. Bu nedenle savaştan zarar görmüş çocuklar için en kısa zamanda rehabilitasyon programları uygulanmalıdır. Toplumun gelecekteki refahı da göz önünde bulundurulup, çocuk hakları sözleşmesi çerçevesinde hareket etmek önemlidir.

$\mathrm{Bu}$ yazıda savaşın çocuklar üzerindeki sağlık etkileri ve bunun yanı sıra savaşa maruz kalan çocuklara yaklaşım değerlendirilmeye çalışılmıştır.

Anahtar sözcükler: Çocuk, Savaş, Sağlık

\section{INTRODUCTION}

They shot my kite, my marbles are snafued.

My little body is vulnerable, my heart couldn't carry those enormous pain.

While the bullets that come on to my body are crumbling the depth of my mind

Broken dreams that smell like death, smell like pain.

I'm a child of war..

In front of the eyes of the world, in anywhere of the world...

Number of children live in the fire line is 250 million nowadays. Recent last decade it supposed that more than 2 million children has died because of wars and consequences of war ${ }^{1,2}$.

Wars have effects that pose significant threat on psychological and social well-beings of civilian population ${ }^{3,4}$. Terror and horridness of war environment is more battering for children than adults. Therefore healing the physiological and psychological damage on children resulted by war and conflicts would not be possible, generally ${ }^{5}$. For these reasons, thousands of those children will bear painful traces of the negative effects of war and conflict on their lives and their feelings as rancor, hatred and revenge that ingenerated in their soul will draw them into conflict again. It would be very difficult to protect children's psychological and physiological health in such an environment ${ }^{5}$.

This article attempts to assess the impact of war on children, as well as approaches to children who have been subjected to war.

\section{The Effects of the War on the Child:}

Death: Thousands of children have been dying because of violence at war every year. Children have become directly target as civil citizens or warriors or died for ethnical reasons. Infant mortality increases during conflicts usually. Preventable diseases such as measles, tetanus and diphtheria may be epidemic at war. In regions affected by conflicts, eradication of infectious diseases such as poliomyelitis is interrupted because of the remnants of the disease. Approximately 250 thousand people have lost their lives in the Syrian Civil War that has been going on since 2011. About 12 thousands of them are children ${ }^{6,7}$.

Injuries and Mutilation: Children are confronted with war injuries in various forms. Some weapons affect children in particular. Mine explosion causes more deaths or serious injuries in children than adults. Thousands of children are exposed mine injuries. The most important heritage of a contemporary war is injuring of children by land mine. As a result of the explosions, injuries such as foot and lower limb injuries, genital injuries, blindness and deafness develop in children. A large number of these children are not able to benefit from adequate rehabilitation facilities due to their disability ${ }^{6}$.

Disease: Damage on health system of a country where effected from conflicts threats children lives. Because of destroying of substructure, lack of qualified personnel, equipment and medicine, restraining to reach health services for mother and newborn increase mortality in civil population $\mathrm{UNICEF}^{8}$.

Lack of immunization during conflicts and war, mass movements and collective life in the camps, more exposing to vectors and contaminated waters, reducing of public health campaigns and inadequate healthcare increase the rate of infectious diseases. Refugee children are more susceptible to death when infectious diseases are associated with malnutrition.

Immunization programs of population may be interrupted in the event of war, which may be responsible for an increase in child mortality $6,9,10$, 11. Following the polio cases at Syria in 2013, more than 1 million children were vaccinated against measles and polio; more than 1,3 million children were vaccinated in the scope of elimination of polio campaign by Ministry of Health in $2015^{12}$.

Torture and Rape: During the conflicts, children are subjected to torture, or they directed to participate in the massacres that have done, or to observe at least what is happening. Children in 
conflicts have become witnesses to death of their parents or siblings or their beloved ones. Sexual violence and rape are used as a weapon for ethnic cleansing ${ }^{9}$. These conditions, which are frequently encountered during wartime, can lead increasing of sexual transmitted disease and mortality from these diseases and cause psychological problems ${ }^{6}$.

Sexual violence is a torture and war crime and crime against humanity. Nevertheless, despite the adoption of United Nations Resolution 18206, which calls for the halt of sexual violence against civilians in conflict areas, children still suffer from this situation ${ }^{13,14}$. It was reported that more than 20 thousands of girl were raped during civil war in Bosnia Herzegovina.Children who experienced sexual violence have health problems, including long-term psychological trauma, infections such as HIV / AIDS and early gestation ${ }^{15}$.

Psychological influence: Experiences of war includes some mental health problems as posttraumatic stress disorder (PTSD), depression, anxiety and behavior disorders ${ }^{16}$. Post-traumatic Stress Syndrome could be developed as a result of influence of terror and tragic events children exposed during war. Severe loss and disruption in their families lead to depression and anxiety, children influenced war. Exposing to violence and influence from loss become extended in immigration conditions. Psychosomatic disorders, suicidal behavior, domestic violence, alcohol dependence and antisocial behavior may also occur 6 .

Forced migration: War and violence force millions of people to leave their homes. During migration, $5 \%$ of children lose their parents. Mortality is very high among children separated from their families because of war.85\% of the deaths are seen within the first 2 days after reaching to refugee camps. Implementing of early and appropriate care approaches to these children reduce mortality 9 . Other children are experiencing problems, such as loss of language and tradition, and disapproval in the regions. For these reasons, thousands of children are forced to carry the negative effects of the war throughout their lives.

The United Nations High Commissioner for Refugees estimates that at least 60 million people have fled their homes by 2015 due to conflict and violence $\stackrel{2}{2}$. The greatest population movement that the world has experienced since the Second World War is in Syria today ${ }^{15}$. Almost 2.8 million Syrians that supposed that half of them were children are under temporary protection of Turkey where the largest number of Syrian refugees in the world. Less than $10 \%$ of the Syrian refugees live in 23 official camps along the Syrian border while the remaining $90 \%$ reside outside the camp mostly in the south-east, and increasingly in the northern and western cities of the country ${ }^{12}$.

Children soldiers: Children working on behalf of armed groups are used by soldiers for sexual purposes (especially girls) or marriage as well as jobs such as cooking, carrying news and materials, making propaganda, being human shields, being in hot conflicts. All these children are called as "Child Soldiers" whether they are using guns or working in armed groups. Sometimes children can also participate in armed groups in order to get rid of their needs such as food, clothing or protection ${ }^{9,13}$.

In 2002, the Optional Protocol to the Convention on the Rights of the Child to the Convention on the Involvement of Children in Armed Conflicts was adopted and entered into force. In the same year, the Rome Statute of the International Criminal Court entered into force and the use of children under 15 years of age in the army, armed or in conflict was considered a "war crime" 5 . The Law No. 4991 dated 16.10.2003 on the Adoption of the Optional Protocol to the Convention on the Rights of the Child on the Involvement of Children in the Armed Conflict has been passed in the TBMM ${ }^{13}$

Deprive from education: Children deprive from educationsuch as forcing to migration or destroying of schools in conflict areas. 490 thousands of 870 thousands of Syrian children in school age have education in our country ${ }^{12}$.

Loss / Absence of Parents: Although it is not known that children exposed to war-related traumas are exposed to traumatic psychological morbidity speculation, children whose parents deployed for ready to war missions could have psychological disorders too. Among the children whose parents work in the conflict area, there are compliance problems due to absence of parents ${ }^{17}$, 18.

Socio-cultural Change: Children may have to move away from their own society and culture during the war ${ }^{6}$. For this reason, there are problems such as the loss of language and tradition $^{17}$. 


\section{Approach and Suggestions to the Child Subjected to War:}

Children can be affected in a variety ways by experiencing death, injury and disability, disease, torture and rape, psychological influence, migrant work, child soldiers, deprivation of education, loss of parents, socio-cultural change due to war. In addition, destructive effects of war occur in different forms and grades on children due to factors such as age and gender. For this reason, gender, age, developmental period characteristics of children should be considered in rehabilitation studies and short and long term coping mechanisms should be established in this direction. Priority should be given to children who have suffered physical and sexual abuse and have lost family members $9,16,17$.

Newborn and infancy periods (0-11 months): Loss of parent negatively affects baby's physical and psychosocial development. Especially in this period, babies who cannot receive breast milk due to loss or other reasons should be supported. The ongoing experience in infancy and the frequency of meeting the needs provide the development of confidence. The nature of the caregiver-infant relationship is the basis for this feeling. For this reason, the baby caregiver must be changless ${ }^{19,20}$.

Early childhood (1-3 ages): In this period the activity frequency increased. Necessary precautions should be taken to protect the child against trauma. The game for growth and development is as effective as food.Playing is very important, especially when motor skills, language and social skills are not developed. Safe playgrounds should be organized for the children to play the game ${ }^{19,21}$.

Preschool period (3-6 ages): Required safety precautions should be taken. The child needs to be able to learn to communicate and social skills and to be able to play with others and be accepted. Wherever possible, family uniformity should be ensured so that the child can be routinely rotated. It is the period when basic habits are acquired. Development of motor development and activities can become dangerous ${ }^{19,21}$.

School-age period (6-12 ages): At these ages, individual personality traits emerge. Since children can talk and imagine everything in this period, they reinforce concrete decisions. The humiliation of the child's activities creates conflict. Individual achievements should be supported. In order to prevent possible aggressive or self-harmful behaviors following traumatic experiences, the interest and supervision of children should also be increased. Areas where they can perform activities such as games, music, dance, painting, singing, storytelling should be played ${ }^{19,21}$.

Puberty period (12-20 ages): Peer relations are important in the puberty period.The provision of family unity, school environment and peer support alleviate the negative effects of war on psychological health ${ }^{22}$. Instead of (or in addition to) psychological therapies during support programs, psycho-educational and educational programs can strengthen such skills and actively activate children's voices in the process of suffering and suffering ${ }^{23}$.

\section{CONCLUSION}

The consequences of armed conflicts are primarily effect children for they are undefended and vulnerable, and this occurs in very different and various ways. War and violence environment have effect also on unborn children as children of these days as in negative way. Therefore implementation of rehabilitation programs for war-torn children should be bringing into force as soon as possible. It's important to act in the frame of Convenient of Rights of Children by considering the future well-being of the society.

\section{REFERENCES}

1. Bertania A, Mathieub, J, Dahanc L, Launayd F, Rongiérase F, RigalfS. War-related extremityinjuries in children: 89 cases managed in a combat support hospital in Afghanistan Orthopaedics\& Traumatology: Surgery \& Research 2015; 101: 365-68.

2. Humanitarian Action for Children 2016 (Overview) https://www.unicef.org/hac2016/. Retrieved May 2, 2017.

3. Vindevogel S, De-Schryver M, Broekaert E, Derluyn I. Challenges faced by former child soldiers in the aftermath of war in Uganda Journal of Adolescent Health 2013; 52: 757 64.

4. Çelikel A, Karbeyaz K, Kararslan B, Arslan M, Zeren C. Childhood casualties during civil war: Syrian experience Journal of Forensic and Legal Medicine 2015; 34 1-4.

5. Bilgin R. Çatışma ve şiddet ortamında büyüyen çocuklar sorunu Fırat Üniversitesi Sosyal Bilimler Dergisi 2014; 24:1, 135-51.

6. Çocuklar ve savaş, Hasuder Yayın, Elektronik Kitap 
http://halksagligiokulu.org/anasayfa/compone nts/com_booklibrary/ebooks/\%C3\%87OCU KLAR\%20VE\%20SAVAS_HASUDER\%20 YAYIN\%20NO_2014_2.pdf. Retrieved May 4, 2017.

7. Er E, Çorbacioğlu ŞK, Güler S, Aslan Ş, Seviner M, Aksel G, Bekgöz B. Analyses of demographical and injury characteristics of adult andpediatric patients injured in Syrian civil war, American Journal of Emergency Medicine 2017; 35:82-6.

8. UNICEF The State of the World's Children. https://www.unicef.org/sowc2016/. Retrieved May 4, 2017.

9. Yurdakök K. Savaş ve Çocuk, Turkiye Klinikleri J PediatrSci 2008; 4: 62-6.

10. Hossain M, Leidman E, Kingori J, Harun AA, Bilukha O. Nutritional situation among Syrian refugees hosted in Iraq, Jordan, and Lebanon: cross sectional surveys, Conflict and Health 2016; 10: 4-11.

11. Oğuz S, Tuygun N, Polat E, Akça H, Karacan CD. Savaş ve çocuk: Suriye iç savaşının sınırdan $750 \mathrm{~km}$ uzaktaki bir çocuk acil servisine etkisi. J Pediatr Emerg Intensive Care Med 2016; 3: 135-9.

12. UNICEF for every child http://www.unicef.org.tr/files/bilgimerkezi/do c/Children\%20of\%20Syria_01.2007_TR.pdf. Retrieved May 10, 2017.

13. Polat $\mathrm{O}$, Güldoğan E. Çocuk askerler: Psikolojik, sosyal ve fiziksel sorunlar, Uluslararası Güvenlik Ve Terörizm Dergisi 2010; 1: 105-24.

14. Ba I, Bhopalp RS. Physical, mental and social consequences in civilians who have experienced war-related sexual violence: a systematic review (1981-2014) Public Health 2017; 142: 121-35.

15. Children and armed conflict. https://childrenandarmedconflict.un.org/graca
-machel-report-20th/__Retrieved May 10, 2017.

16. Amone-P'Olaka K, Ovugab E. The influence of types of war experiences on conduct problems in war affected youth in Northern Ugandan: Findings from the WAYS study, Psychiatry Research 2017; 251: 14-19.

17. Shaw JA. Children Exposed to War/Terrorism Clinical Child and Family Psychology Review 2003; 6: 237-46.

18. Turnera HA, Finkelhora D, Hambyb S, Henlya M. Victimization and adversity among children experiencing war-related parental absence or deployment in a nationally representative US sample Child Abuse \& Neglect 2017; 67: 271-9.

19. Erden G, Gürdil G. Savaş yaşantılarının ardından çocuk ve ergenlerde gözlenen travma tepkileri ve psiko-sosyal yardım önerileri Türk Psikoloji Yazıları 2009; 12: 113.

20. Gözübüyük AA, Duras E, Dağ H, Arıca V. Olağanüstü durumlarda çocuk sağllğı, Journal of Clinical and Experimental Investigations 2015; 6: 324-30.

21. Conk Z, Başbakkal Z, Bal H, Bolışık B Pediatrihemşireliği, Akademisyen Tip Kitabevi. 2013. 80-4.

22. Foster H, Brooks-Gunn J. Children's exposure to community and war violence and mental health in four African countries, Social Science \& Medicine 2015; 146: 292-9.

23. Veronese G, Pepe A, Jaradah A, Murannak F, Hamdouna H. "We must cooperate with one another against the Enemy": Agency and activism in school-aged children as protective factors against ongoing war trauma and political violence in the Gaza Strip, Child Abuse \& Neglect 2017; 70:364-6. 